\title{
A Cartel that Lasts for Centuries: The Case of the Eastern Orthodox Church Indulgences
}

\author{
Kostas Axarloglou ${ }^{1}$ Christos Cabolis ${ }^{2} \quad$ Nikos Chrissidis $^{3}$
}

This Draft: January 16, 2012

\begin{abstract}
In this paper, we present a non-conventional case of collusive behavior and tactics that last for centuries. In particular, we focus on the process through which the Patriarchates of the Eastern Orthodox Church (specifically, those of Constantinople, Jerusalem, Antioch, and Alexandria) distributed indulgences to believers in their jurisdictions during the period between the sixteenth and the seventeenth centuries. By employing a wide variety of primary sources such as correspondence among the various patriarchates and among individual clerics, printing orders for indulgences, and income-expenditure records among others, we present evidence of oligopolistic interaction and behavior among the various Patriarchates in the distribution of indulgences. The observed long duration of this collusive structure is the outcome of high barriers to entry, well defined market segmentation, effective monitoring, a strong enforcement mechanism and finally little product innovation. Overall, the data suggest that, besides their spiritual importance, indulgences were promoted in a way that resembles very much the distribution method and process of any typical product in a modern market economy.
\end{abstract}

\section{This is a preliminary paper on the topic. Please, do not cite or quote without permission from all authors.}

\section{JEL Classification: A12, D12}

Key Words: Indulgences, Oligopolistic Interaction, Price Discrimination.

\footnotetext{
${ }^{1}$ Department of International Economic Relations and Development, Democritus University of Thrace, 69100, Komotini, Greece; e-mail: axarlog@otenet.gr

${ }^{2}$ ALBA Graduate Business School and Yale International Center for Finance, ALBA, 2A, Areos Str. \& Athinas Ave., 16671 Vouliagmeni, Athens, Greece; e-mail: ccabolis@ alba.edu.gr

${ }^{3}$ Dept. of History, Southern Connecticut University,501 Crescent Street, New Haven, CT. 06515-1355, USA; e-mail: chrissidisn1@ southernct.edu
} 


\section{Introduction}

Collusive behavior, one of the many types of strategic interaction in an oligopolistic market structure, has drawn a lot of interest among researchers. As Levenstein and Suslow (2006) point out, cartels, the outcome of collusive behavior, are short-lived (on average they last for five years), and only in very rare cases, they can last for few decades. In our paper, we present evidence of cartelization in distributing indulgencies in the Eastern Orthodox Church that actually lasts for centuries. ${ }^{4}$ In the paper, we analyze the key elements that contribute to the long duration of this particular cartel that boil down to strong barriers to entry, a strong enforcement mechanism of the collusive agreement, a strong coordination and communication mechanism among the key distributors of indulgencies, and finally a lack of any product/service innovation on indulgencies for centuries. Moreover, our study contributes in the relevant literature since it analyzes collusive behavior and practices that are centuries old, are pursued by nonstate religious institutions (i.e. the patriarchates) and, finally, refer to a supranatural, spiritual product such as indulgencies.

Levenstein and Suslow (2006) summarize the findings (both theoretical and empirical) on cartel duration from various studies. Market structure and developments (such as market concentration, barriers to entry, market demand uncertainty, etc), communication and coordination among competitors, implementation of the cartel

\footnotetext{
${ }^{4}$ Indulgences are letters of remission and/or absolution of sins. Indulgences are usually associated with the Roman Catholic Church. However, it is also known that the Eastern Orthodox Church has issued and distributed indulgencies to the faithful at least since the late $15^{\text {th }}$ century. See the seminal articles of Filippos Iliou (1983) and (1985).
} 
enforcement mechanism, and product characteristics (such as inelastic product demand) are the key factors that influence the duration of cartels. In particular, Dick (1996) attributes cartel formation in industries where companies have significant market power and show high barriers to entry. Greeif (1993), Gensesove and Mullin (2001) and Humphrey and Ruseski (2009) among others analyze the importance in cartel duration of a cartel enforcement mechanism, the establishment of specific rules among cartel participants and also the continuous communication among these participants. Porter (1983) and Suslow (2005) among others point out to market demand fluctuations and market demand uncertainty as key factors that influence cartel duration. Finally, Symeonidis (2003) finds that collusion is more likely in high capital intensive industries (and thus in industries with higher barriers to entry) and also in industries with low advertising expenditure (and thus in industries with rather homogeneous products).

In our paper, we analyze the reasons of a successful cartelization in distributing a supranatural product (indulgencies) by religious institutions (Patriarchates) that lasts for centuries. Iliou (1983) notes that indulgences are circulated from the $15^{\text {th }}$ century until at least mid $20^{\text {th }}$ century. As argued in the paper, despite the religious insitutions structure, collusive practices are similar with the ones in more conventional industries and also can lead in very much unexpected and much longer duration of cartels. Moreover, certain elements appear to contribute to the centuries-long duration of the cartel that are not that different from more conventional industries and market structures.

In particular, following the relevant literature (see Iliou $(1983,1985)$ ) we analyze the process through which the Patriarchates of the Eastern Orthodox Church (specifically, those of Constantinople, Jerusalem, Antioch, and Alexandria) distributed 
indulgences to believers during the period between the sixteenth and the nineteenth centuries. Analysis of the data presents evidence of collusive interaction and behavior among the various Patriarchates in the distribution of such letters. Specifically, this interaction involved tactics such as market segmentation, an effective monitoring and a strong enforcement mechanism to implement market segmentation, high barriers to entry, effective collaborative behavior among Patriarchates in enforcing the above segmentation and finally a product (indulgencies) that has experienced absolutely no innovation in terms of its attributes through the centuries. Overall, evidence suggests that, besides their spiritual importance, indulgencies were distributed in a way that resembles very much the distribution methods and processes of a typical product in a modern market economy. Moreover, these distribution methods and structure show remarkable stability that lasts for centuries.

The analysis in the paper depends on a wide variety of primary sources (in Greek as well as in Slavic languages) such as correspondence among the various patriarchates and among individual clerics, printing orders for indulgences, income-expenditure records, historical and anecdotal accounts of inter- and intra-patriarchal conflicts concerning jurisdiction for the distribution of indulgences, etc.

In section 3, we analyze evidence that provide details on the demand and supply of indulgences. In section 4, we present evidence of the evolution of the market for indulgences. More specifically, we present evidence that the Patriarchs were distributing indulgences to the faithful in ways that resemble practices of strategic interaction among oligopolists. We begin our analysis with the study of the product indulgence in the following section. 


\section{The Product}

Indulgences are the extra-sacramental written remissions of the temporal punishment due to sin. For a believer, a patriarchal indulgence was above all a public certificate that all his or her sins were absolved and that salvation was guaranteed by the highest authorities in the Church, not simply through the absolution of their own father confessor. Indulgencies were also an act of exhibiting piety and showing respect to the highest authorities in their Church, a way to guarantee salvation, and in some ways, a mechanism through which believers could counter the obstinacy or power that their own problematic priest had over them.

As a manifestation of Orthodox religious life, Eastern "indulgences" constitute an example of a Western influence dressed in Orthodox garb. At a very basic level, patriarchal indulgencies prove that the Eastern Orthodox actively sought salvation not only by conforming to customary confession and penance, but also by employing newly invented roads to heaven. Especially important in this regard was the fear that a person would die without fulfilling canonical penance. In a general sense, then, indulgencies served as a written guarantee of salvation, as a relaxation of the fetters imposed on penitents, and as a certificate that the recipient was in good standing in the eyes of the highest church authorities, and through them, of God.

In the early times of the practice, indulgences were granted by any cleric at the top echelons of the church hierarchy. Indulgences were addressing, among other things, the much needed metaphysical anxieties faced by those denied communion or those 
burdened by a curse or those who had incurred the displeasure or wrath of their own priest. The case of the dispute between the priest and the parishioners of the Greek brotherhood of Napoli in the late sixteenth century is an illuminating case. The disagreement stemmed from the priest's latinizing tendencies and ended up in the courts of the local Roman Catholic archbishop. In the course of the investigation, the Roman Catholic authorities discovered that a substantial number of the parishioners, were holders of Eastern indulgences issued not only by patriarchs but also by archbishops. ${ }^{5}$

Throughout the Eastern Orthodox world, indulgencies for the most part cut across social and cultural boundaries. Orthodox believers actively manipulated the economic needs of itinerant prelates, especially patriarchs, who in effect acted as peddlers of salvation. Granting indulgences was generally accepted to be the prerogative of patriarchs, although, as we will discuss below, there is some evidence that archbishops and bishops also succeeded, for a relative brief time, at asserting the authority to issue written remission of sins.

While the outcome of this intra-ecclesiastical war over status and over who enjoys the authority to save the soul of the believers was unfolding, the believer could safely accumulate as many such letters as he or she could. The more the official guarantees, the better off the believer was. And even after the successful elimination of competitors by the Eastern patriarchs, there was still a choice. Believers could and did in fact collect letters of absolution from any patriarch they could. ${ }^{6}$

Of course, in our analysis we approach indulgencies as typical products that satisfy certain human needs and we abstain from analyzing the theological meaning of

\footnotetext{
${ }^{5}$ For a detailed account of the incident see Nikas (1998).

${ }^{6}$ See Likhachev (1894) p. 78 and the references in Iliou (1983), p. 44.
} 
indulgences in Christianity. In this context, individual believers obtain indulgences in order to meet some of their spiritual needs, and thus, they are willing to pay in obtaining an indulgence. This is quite evident in the income lists of the Jerusalem Patriarchate. ${ }^{7}$

Theologically, indulgencies never became the focus of sustained discussion in Eastern Orthodox Church. However, as the example of the Greek Brotherhood of Napoli indicates above, there is evidence that helps clarify the value of indulgences to the faithful. The Orthodox community of Napoli was, of course, situated in a area of predominately Roman Catholic believers. Until other evidence becomes available, the conclusions that we can draw necessarily appear tentative. At most, these depositions offer us some insight into the microcosm of the individual Eastern Orthodox recipient of patriarchal indulgence.

Unfortunately, it is quite difficult to find prices for indulgencies for earlier periods. However, in the second half of the $17^{\text {th }}$ century, we have found, in the files of the Patriarchate of Jerusalem, important information and data that are directly associated with the monetary return for the provision of indulgences. We learn, from Patriarch (of Jerusalem) Dositheos that the distribution of indulgences is associated with monetary gain. For instance, in another 1696 letter to the brotherhood of the Holy Sepulcher,

\footnotetext{
${ }^{7}$ For instance, see the following evidence:

- [On] March 30, 1736: "we received from synchōrochartia. Zolōtia 48."

- [On] April 19, 1737: “[we received] from synchōrochartia. Zolōtia 25."

- [On] April 8, 1745: "we sold some synchōrochartia. Zolōtia 38"

- [On] April 1, 1749: "we sold some synchōrochartia to the pilgrims. Zolōtia 30."

- [On] May 4, 1753: "we received from the sale of synchōrochartia. Aslania 25."

- [On] May [1753?]: "from the sale of synchōrochartia. Aslania 4."

The source of the information above is Patriarchate of Jerusalem, codex VI.D, no. 2, ff. 27v, 30v, 55v, 62v, 75,78 respectively. The older zlotes/zolotia were slightly less in value than the new ones. 1 old zlota: 88 aspra. See also Stathē (1984), p. 200, fn. 67. The new zlota was equivalent to 90 aspra: ibid, 198, fn. 55.
} 
Dositheos instructed them: "Whoever gives aspra, gets indulgences; whoever does not should never get one even if they are available." ${ }^{\prime 8}$

Despite the fact that the income generated from the sale of indulgences was considerable, the information that we have relative to the price charged by the patriarchs is limited, especially for the $16^{\text {th }}$ and $17^{\text {th }}$ centuries. The main source of information that we found is a travelogue that Patriarch Chrysanthos, the nephew and successor of Patriarch Dositheos, kept while visiting Orthodox communities in Asia Minor and the Balkans. Table 2 provides the number of indulgences as well as the total amount paid that is referenced in Patriarch Chrysanthos's travelogue.

Insert Table 2 about here

As can be seen in Table 2, Chrysanthos' visit to four villages in the island of Chios was quite successful in monetary terms. All in all, as Stathē suggests, only in those four villages, Chrysanthos gave out 224 indulgencies for a total of 155 grosia. This is a rather large number of indulgences for the island for a substantial monetary return. ${ }^{9}$

\footnotetext{
${ }^{8}$ Patriarchate of Jerusalem, VI.6, no. 12 p. 841. As Liata (1999) p. 90, suggests, the terms aspra frequently meant simply money, not necessarily the specific numismatic unit called aspra. The letter contains a series of instructions to the brotherhood on how to deal with every day matters concerning pilgrims as well as with the administration of the patriarchate's establishments. On coinage in the $18^{\text {th }}$ century, see among others Liata (1999), Svoronos (1956), p. 116-117 and Kremmydas (1972) p. 110-120.

${ }^{9}$ In a recommendation letter addressed to the clergy and laity of Chios, the Patriarch of Constantinople (in whose jurisdiction Chios was) praised alms-giving as an act pleasing to God and helping souls escape hell. $\mathrm{He}$ also specifically singled out monetary help to temples, churches and pilgrimage sites as a most divinelyapproved act. In particular, financial help to the Holy Sepulcher was the most glorious such act a believer could engage in given that the Holy Land was the place where the drama of salvation was played out. Therefore, the patriarch urged his flock to give generously to the representatives of the Holy Sepulcher since "it is the common pilgrimage site of the Orthodox." He then referred to the previous visit of Patriarch Chrysanthos of Jerusalem, at a financially difficult time for the island, and praised the inhabitants' willingness to set up collection boxes and to act as commissioners for money collection. Through this letter, the Patriarch of Constantinople urged the Chians to continue down the same path and to ensure that these efforts will continue into the future as well: the letter probably dates 1726-27 when Paisios II was the
} 
Moreover, if we take into consideration only the pairs of observations that we have indications for units provided and amount received then we have 207 indulgences for a total of 162 grosia, an average price of .78 grosia. From the data we have, it is not clear whether this is a fixed or "suggested" price. Thus we cannot determine whether believers were allowed to acquire an indulgence at a lower price than the suggested one, or whether the Church was performing a policy of price discrimination of first degree where the required price was a function of the believer's economic well being.

Most importantly, the data underline the high value believers were placing in indulgences. To place the price of an indulgence in perspective, we rely in the work of Chaviaras (2003) who points out that in the area of Thessaloniki in 1724, the price of a sheep was 65.5 aspa while a guard was receiving 23 aspra for a day of work. ${ }^{10}$ Liata (1999) provides an exchange rate of 120 to 180 aspra per grosi for the year 1721 in Thessaloniki. ${ }^{11}$ Thus, the price of an indulgence was approximately equal to two sheep or five days of work for a guard. This implies that the acquisition of an indulgence was a purchase that a believer had to plan for.

Relying in Chrysanthos's account we determine that the demand for indulgencies is stronger in areas where Roman Catholic and Eastern Orthodox populations lived in close proximity. The Roman Catholic practice of indulgences may, therefore, have contributed to this heightened demand. ${ }^{12}$

Patriarch of Constantinople. Chrysanthos was in Chios Sept. 1725-Febr. 1726. See Zolōtas (1928) part 2 in p 224-28.

${ }^{10}$ Chaviaras (2003) also outlines that each household had to pay 30 aspra to the tax collector for his services and 600 aspra annually as a real estate tax.

${ }^{11}$ Liata (1999) also provides that in Anatolia, for the year 1725, the exchange rate was 120 to 186 aspra per grosi.

12 According to Francesco Lupazzolo (in his Isolario written 1638) the villages of Chios mentioned in Chrysanthos' account were inhabited by Greeks and the plain around them was used during the summer months and in cases of the plague as a refuge from heat and disease. See Argentē and Kyriakidēs, eds., 
Affordability of acquiring indulgences did not seem to be an issue given what we know about their prices. At issue, however, from the patriarchates' point of view was not the economic but the spiritual gain. From our research, it seems that other sources were contributing more to the income of the Patriarchates. For example, the believers' obligatory annual contributions to the patriarchates were much bigger in terms of sums. ${ }^{13}$

Indulgencies emphasized, confirmed and reinforced the spiritual authority of the issuers and their unique prerogatives in issuing them. Thus, the spiritual dimension of existential security on the part of the receiver was coupled with the certainty that these certificates of piety were in fact valid, effective and desirable given that they were issued by the only ones entitled to doing so.

As it becomes apparent, believers in the Eastern Orthodox Church did find significant spiritual value in receiving indulgences and they were willing to pay in order to obtain them. So, in an economics sense, indulgences appear to have the fundamental characteristics of a typical "product".

\section{Distribution and Planning}

(1946), p. 185-186. It is also known that the Jesuits and aristocratic families of the island had summer residences in the villages of Thymiana and in Tholopotami. In general, the whole area called Kampos, close to the sea, was a favorite of rich families for the summer months according to evidence from the second half of the $17^{\text {th }}$ century: see e.g., Argentē and Kyriakidēs (1946) vol. 1, pp. 280, 324; RoussosMelidonēs, (nd) p. 160. The Jesuits also had bought a Byzantine Church in 1635, Hagios Vlasios, in the area of Kampos: according to $17^{\text {th }}$ ce. evidence, the church was counted among those commonly used by both Catholics and Orthodox: see Roussos-Melidonēs (1991) p. 92. After the events of 1694-1695 (Venetian conquest of Chios followed by Turkish reconquest), the Catholic community fell into decline. In 1755 it numbered 1,600 and in 1822, 400. But after 1718 and the Treaty of Passarowitz, the situation did improve. Some churches were returned to the Catholics: ibid, 108 and 112-120 (on the decline in the $18^{\text {th }}$ ce.). Richard Pococke, who visited Chios in 1739, repeated much the same information regarding the use of the Kampos villages as refuge from heat and disease. See Argentē and Kyriakidēs, eds. (1946) vol. 2, p. 671-73.

${ }^{13}$ See Konortas (1983) 
The first indication of distribution of indulgences is dated in 1576 when Theodosios Zygomalas, the protonotarios of the Patriarchate of Constantinople, visited several Aegean islands as a patriarchal exarch. During his sojourn at the islands, he apparently requested indulgencies from Patriarch Ieremias (first patriarchate: 1572-1579) in order to distribute them. Through correspondence, the Patriarch informed Zygomalas that he only had 62 such documents ready, which he was sending him, but also promised soon to dispatch more. ${ }^{14}$ These were hand written documents. However, given the number of the indulgences, as well as the fact that the final recipient was not known in advance, we assume that there was a standardization of the text.

Records of subsequent distribution of indulgences are found again half a century later, in 1639, when 35 synchōrochartia of Patriarch Parthenios I of Constantinople (the so-called gerōn, 1639-1644). These manuscripts include a blank area for the name of the recipient. Interestingly, they were not used during the mission of the Patriarchate of Constantinople to Crete. ${ }^{15}$

A few years later, we have accounts of the first printed indulgences. In the midseventeenth century, Moscow's Printing Office (Pechatnyi Dvor), which was under the control of the Russian Orthodox Church, became a major alternative outlet for Greek (and some Serbian) prelates in search of printing presses for their charters of remission. During the $17^{\text {th }}$ century we found references for a total of 5000 indulgences. Table 1

\footnotetext{
${ }^{14}$ Crusius (1584), p. 293. It should be noted that Crusius translated the term synchoretika grammata as litterae veniales.

${ }^{15}$ Iliou (1985), p. 18, citing Chasiotēs (1969), 201-236, here 203-204. It should be noted that there were separate letters for women and men whose text only differed in terms of the corresponding gender.
} 
presents information on the issuer as well as the year and the number of these documents. $^{16}$

Insert Table 1 about here

As expected, printing on one hand requires standardization of the text and, on the other, allows for the production of greater number of documents.

The files of the Patriarchate of Jerusalem provide answers to two important issues that were relevant in the second half of the $17^{\text {th }}$ century. First, how many indulgences can a believer acquire, and second, to how many people can a single indulgence being issued for.

The answer to the first question can be found in a 1696 letter to the brotherhood of the Holy Sepulcher, from Patriarch Dositheos II of Jerusalem (1669-1707). Patriarch Dositheos warned the brotherhood to give only one indulgence to each chatzēs (that is, pilgrim to the Holly Land) and not more. ${ }^{17}$ Obviously, Dositheos was worried about the

${ }^{16}$ See Appendix 1 for detailed account of the information presented in Table 1.

${ }^{17}$ Patriarchate of Jerusalem, VI.6 (Codices of the Head Secretariat), no. 12 (epistles of Dositheos), p. 501. References to indulgences are made in several other letters of the same collection. On the pilgrimage to Jerusalem, see among others, Chrysochoidēs (2003), p. 99-110, where he suggests that in the $17^{\text {th }}$ century there was a dramatic increase in the number of pilgrims to Jerusalem, something he attributes to the rising tensions between Orthodox and Latins for control of the pilgrimage sites. Also, according to him, the anelastikes dapanes (obligatory expenses) involved the following: the filotimo (usually one grosi given when a pilgrim was registered in the list of pilgrims kept by the Patriarchate of Jerusalem; the plysimo podarion (washing of feet); candles and the diskos (collection tray); finally, the enrollment of the pilgrim (and also if he so wanted members of his family) in lists for parrhesia, prothesis or sarantaria, all of them memorial lists for various church services: ibid, 108-109. At the very end of the $19^{\text {th }}$ ce., according to the Archpriest Kl. Fomenko, pilgrims in Jerusalem ordered "absolutory liturgies" (razreshitel'nye liturgii) that took place in the Church of the Resurrection. These liturgies were performed by bishops who after the Gospel reading, would ask all those who had ordered such a liturgy to kneel down. The he would kneel too, and read short prayer in Greek: this prayer was the one contained in Greek and Slavonic synchōrochartia. Thereafter, some of the pilgrims would take communion. See Fomenko (1900) p. 9981000 . 
possibilities of abuse and aimed at safeguarding control of the distribution in the brotherhood's and the patriarchate's hands.

Regarding the second question, we should note that collective indulgencies were not an infrequent practice. Normally, they were offered to monks of a particular monastery, but there were also cases of such collective indulgencies given to professional associations or other groups of people. ${ }^{18}$

The above provided evidence indicates that indulgences were produced in volumes and were provided either to individuals or even to groups (professionals or villagers). However, evidence shows that clergy who tended to distribute indulgences to the faithful were planning their orders in advance since it was taking quite some time (i.e. lead time) until indulgences were available for distribution.

All in all, these are elements of well planned and consistently organized operation to supply to the faithful indulgences in order to cover their spiritual needs.

\section{What Stabilizes a Cartel}

\subsection{Cartel Stability and Longevity}

\footnotetext{
${ }^{18}$ For instance, in 1641, the Patriarch of Alexandria Nikephoros (1639-1641) supplied a number of indulgences for the inhabitants of Kydonies, Crete (see Iliou, 1983). Moreover, the Patriarchate of Constantinople sent a collective indulgence (dated between 1731-1737 and co-signed by Patriarch of Jerusalem Meletios and other prelates) to the fur-makers who had previously ignored rules established by the patriarchate regarding their trade. This letter forgives them for their disobedience and repeats the rules for future reference. The letter eliminates all curses and excommunications to which they had been subjected. Also, in August 1800, Patriarch of Constantinople Neophytos VII along with the patriarchs of Antioch and Jerusalem and another eight prelates sent a collective indulgence to shoe-makers. Apparently the more signatures under the letter, the more official the letter was and, therefore, the better guaranteed its efficacy (see Pallas, 1955). Finally, an association of stone cutters in Chios received from Patriarch Chrysanthos of Jerusalem (1797-1731) 12 individual indulgences as payment for collective work in 1725.
} 
Collusive behavior and tactics are frequently observed in oligopolistic market structures. However, as Stigler (1964) claims, a collusive pact is rather fragile since each one of the oligopolists has an incentive to lower prices and undercut one's competitors. Actually, Levenstein and Suslow (2006) show that most cartels last only for few years, on average, about five years. This is because cartel members have strong incentives to deviate from the collusive agreement especially in the absence of an effective mechanism of monitoring the behavior of cartel members. They also present evidence of a limited number of cartels that managed to last for few decades. They claim that this usually happens because cartel-members manage to develop effective monitoring processes, quick punishment mechanisms and strong barriers to entry towards new entrants.

To illustrate these issues assume a symmetric duopoly, where each competitor charges the same price $\left(P_{s}\right)$ and has a constant marginal cost $(C)$ to produce and distribute its product. Assume also, and for simplicity, that both companies sell a homogeneous product and thus customer choice depends solely on price. In this case, the two competitors share the market and achieve unit sales of $\frac{D\left(P_{s}\right)}{2}$. However, in case of Bertrand competition, each competitor has an incentive to slightly undercut other competitors in order to acquire the entire market of $D\left[P_{s}\right]$. Of course this draws the reaction of the rest of the competitors, who also undercut prices and this back and forth continues until price equals marginal cost and all competitors break even.

To avoid cut-throat competition, competitors might collude and reach a cartel agreement fixing thus their prices at $P_{s}$. At this case, each duopolist-competitor shares the market and achieves profits of

$$
\pi_{s}=\frac{D\left(P_{s}\right)}{2}\left(P_{s}-C\right)
$$


However, each competitor has an incentive to undercut its price by a bit $\left(P_{c}\right)$ and thus acquire the entire market having profit of,

$$
\pi_{c}=D\left(P_{c}\right)\left(P_{c}-C\right)
$$

Consequently, by undercutting its competitor, the duopolist benefits by $\pi_{c}-\pi_{s}$, which in fact represents duopolist's incentive to deviate from the collusive agreement. From equations (1) and (2), it turns out that $\pi_{c}=2 \pi_{s}$ and thus the benefit for the dupolist to deviate from the cartel agreement is $\pi_{c}-\pi_{s}=\pi_{s}$. Of course, in such a case, any deviation from the collusive agreement will be sooner or later detected and punishment will be imposed on the dupolist that does not maintain the collusive agreement. The imposed punishment usually leads to Bertrand competition and thus prices fall until $P_{p}=C$ and dupolists end up with $\pi_{p}=0$.

Duoplosists now have to decide whether they will maintain the collusive agreement or deviate from it. In this decision-making, where they incorporate their competitors' actions and their own reactions, they should evaluate the incentives to deviate from the collusive agreement against the penalty they might face in case of doing so. As Levenstein and Suslow (2006) review, a collusive agreement is stable when incentives (i.e. benefits) to deviate from it are stronger than the punishment imposed to competitors for breaking the agreement. Under these conditions, a cartel agreement is self-enforcing and credible and as such it lasts for long.

Notice though that the benefits from breaking the collusive agreement accrue over time and of course depend on how long the deviation from the agreement goes unnoticed by the other competitor. In our case, and for simplicity, assume that the deviating duopolist is not detected for one period (which can be a day, a month, etc). As it has been 
showed already, the additional benefit achieved is $\pi_{c}-\pi_{s}=\pi_{s}$. On the other hand, getting caught, the duopolist is punished and ends up with $\pi_{p}=0$ forever. Thus, the forgone profit for the duopolist, in case it is caught, is $\pi_{s}-\pi_{p}=\pi_{s}$ per period, and since the punishment is assumed to be permanent, the present value of the punishment cost becomes,

$$
\frac{\pi_{s}}{(1+r)}+\frac{\pi_{s}}{(1+r)^{2}}+\frac{\pi_{s}}{(1+r)^{3}}+\ldots=\frac{\pi_{s}}{r}
$$

where $r$ is the nominal interest rate for one period.

Overall, the cartel agreement is self-enforcing and credible when the benefits from breaking the agreement are lower than the cost from getting caught and subsequently punished, and thus when $\pi_{s}<\frac{\pi_{s}}{r}$. In other words, the collusive agreement is stable as far as $r<100 \%$, or that the agreement breaks in extremely high interest rates $(r>100 \%)$. Overall, under these conditions, the collusive agreement is very stable.

However, a slower detection of a competitor's agreement-deviating behavior alters the results significantly. For instance, in case that the deviation from the cartel agreement goes undetected for two periods, then the benefits from it become

$$
\pi_{s}+\frac{\pi_{s}}{(1+r)}=\pi_{s} \frac{(2+r)}{(1+r)}
$$

At the same time the cost from getting punished declines and becomes now

$$
\frac{\pi_{s}}{(1+r)^{2}}+\frac{\pi_{s}}{(1+r)^{3}}+\frac{\pi_{s}}{(1+r)^{3}} \ldots
$$


Notice now that the cost from breaking the agreement and being detected after two periods (eq. 5) is equal to the cost of being detected after one period divided by $(1+r)$, and thus equation (5) can be rewritten as,

$$
\frac{\pi_{s}}{(1+r)^{2}}+\frac{\pi_{s}}{(1+r)^{3}}+\frac{\pi_{s}}{(1+r)^{3}} \ldots=\frac{\pi_{s}}{\{r(1+r)\}}
$$

reflecting a lower cost from breaking the agreement. On the other hand, the benefit from breaking the agreement has now increased since $\pi_{s} \frac{(2+r)}{(1+r)}>\pi_{s}$. Consequently, the cartel agreement is now self-enforcing and credible when $\boldsymbol{\pi}_{s} \frac{(2+r)}{(1+r)}<\pi_{s} \frac{1}{\{r(1+r)\}}$, or when $(2+r)<\frac{1}{r}$ and thus $r<41 \%$.

The above analysis indicates that cartel agreements are self-enforcing and credible, and thus they last for long, the sooner any deviation from the agreement is detected (strong monitoring mechanism) and the harsher the punishment is on the competitor(s) that deviates from the agreement (strong enforcement mechanism).

We now turn in presenting evidence that illustrates that the distribution of indulgences in the Eastern Orthodox Church has several similarities with collusive behavior found in a typical oligopolistic industry. We also focus on few dimensions on this collusive behavior that has decisively contributed in to its stability for centuries.

\subsection{Barriers to Entry and Coordination}

Indulgences in the Eastern Orthodox Church appear for the first time in late $15^{\text {th }}$ century, and by all indications, at least in the first century-and-a-half after their appearance, they were issued by clerics of various ranks. Once in printed form, they became available in larger numbers and, therefore, more visible. As a result, in the 
second half of the seventeenth century, the Eastern Patriarchates (and especially those of Jerusalem and Constantinople) sought to monopolize the right of issuing them and used all kinds of measures to stifle any such competition. At the same time, the patriarchs imposed certain rules that privileged the Patriarchate of Jerusalem but also safeguarded the right of other patriarchs to issue their own letters of absolution as long as they did so within their own jurisdictions. The stifling of competition and the introduction of rules of engagement among the patriarchates are found in several instances.

One of the most important and well documented cases is that of Ananias, Archbishop of Sinai, in the second half of the $17^{\text {th }}$ century. Ananias declared his autonomy from any patriarchate and among other innovations he started issuing indulgencies. Patriarch Dositheos of Jerusalem, with the help of various patriarchs of Constantinople, conducted a virtual war against Ananias for daring to issue such letters in the name of abbot Ioannikios. ${ }^{19}$

Ananias' behavior and actions drew the fierce reaction of the patriarchates. Thus, in 1689, Patriarch of Constantinople Kallinikos issued a circular letter to the churches of Moldavia and Wallachia, which was also signed by Patriarch Dositheos (of Jerusalem) and Patriarch Athanasios of Antioch. In this letter, Kallinikos condemned Ananias for pursuing uncanonical and condemnable actions. Among these actions was the issuance by Ananias of indulgences stating that "he [Ananias] even went a bit further in his missteps and he, an abbot, dared distribute printed indulgencies, which is [a right] only allowed to Patriarchs." This statement indicates that issuance of indulgences was the

\footnotetext{
${ }^{19}$ Among the various infractions of Ananias were: that he wanted to be autonomous without any Patriarch supervising him, that he categorized himself with other autonomous archbishoprics such as Ochrid and Cyprus, and that he styled himself makariōtatos. On the history of Sinai, see Amantos (1953). On Ananias, see Gregoriadēs (1875), p. 181-88; Dositheos, Patriarch of Jerusalem (1908), pp. 70, 77, 92, 97, 100, 101, 133; and Iliou (1983) p. 51-53. It should be noted that Ananias had printed indulgences in Ukraine after he was deposed from the position of abbot in Sinai.
} 
right of no other but the patriarchs, and those that would dare do so were condemned. ${ }^{20}$

At the same time this condemnation was discrediting entirely the issuer of the indulgencies and obviously represents a barrier to entry that can not be surpassed.

Furthermore, the patriarchs threatened those who gave credence to Ananias' views and those who accepted indulgencies from Ananias with excommunication because they were accepting these documents which were illegal and invalid. ${ }^{21}$ It should be noted that excommunication is the most serious punishment for a believer. Additionally, in 1691 Patriarch Kallinikos issued another letter in which among other infractions, he condemned Ananias for issuing indulgences. Moreover, at the end of the letter, he announced that by synodal decision Ananias "should not dare distribute to the people the illegal indulgencies (since this is a most distinct privilege of the patriarchs, and in no way can it be transferred to others).,22

In other words, the patriarchs had jointly decided, at a synod, to stop Ananias from issuing and distributing indulgences to the faithful since this was solely their privilege. This actually was clearly mentioned by Patriarch Dositheos who claimed that "except for the patriarchs, whoever [else] in the community of the Church offers

\footnotetext{
${ }^{20}$ Notice that a condemnation by a by the Church theologically puts somebody outside of the church as a heretic. Thus, his actions are entirely discarded by the faithful.

${ }^{21}$ Ta peri tēs eklogès kai cheirotonias Archiepiskopou Sina episēma engrafa, pp. 80-87.

${ }^{22}$ To kanonikon dikaion tou Patriarchikou Thronou tōn Ierosolymōn epi tēs archiepiskopēs Sina, epimartyroumenon hypo Episēmōn Ekklēsiastikōn Engrafōn (1868), 96-106, quote 104. The original of the quote reads: "meth' holōs tolma ta paranoma synchōrochartia ekeina tō laō dianemein, (Patriarchikon gar touto pronomion idiaitaton, kai kat' ouden eis allon diavainein dynatai)..." A bit earlier in the letter, castigating in very stark terms the behavior of the Sinai monks, Kallinikos argued that the Sinai monks had refused to recognize the leadership of the four Orthodox patriarchs in the Church even though "the whole Christendom is walled in (periteichizetai) inside the four Patriarchs:" 102. Another letter by Kallinikos, this one in more demotic style, was addressed to all clergy and all laity everywhere, with similar content: the letter again made mention of Ananias synchōrochartia as paranoma : ibid., 96-103.
} 
indulgencies, bishop or metropolitan or archbishop, even if he is autocephalous, is worthy of excommunication as is the one who receives them."23

Moreover, Patriarch Dositheos claimed that indulgences represented an old custom and tradition, and yet again defended the distribution of indulgences as a patriarchal monopoly. Therefore, Dositheos added, whoever gives them and receives them is accursed because "whatever is done without the Church's agreement is illegal and accursed."

In general, then, the case of Ananias shows that the issue of indulgences was obviously a major concern of all patriarchs, and especially that of Jerusalem. Only patriarchs had the right to issue and distribute indulgences to the faithful and whoever else would decide to do so was penalized spiritually (through condemnation and excommunication). At the same time, even the believers that were accepting indulgencies by a condemned issuer were excommunicated indicating thus strong barriers to entry in distribution of indulgencies that was violating commonly agreed terms among the Patriarchates.

Furthermore, the right of the patriarchs to issue and distribute indulgencies was officially codified in 1709 by a synod in Constantinople. ${ }^{24}$ In other words, the "rules of

\footnotetext{
${ }^{23}$ Dositheos, Patriarch of Jerusalem (1908), pp. 52-70, quote on 70. Dositheos claimed that Ananias "was and still is envious" (ephthonei kai phthonei) of Ioannikios, thus exonerating Ioannikios for the actions of his predecessor. According to Ntore Papastratou, the Sinai monks do not appear to have engaged in the wood cutting or printing themselves, but rather outsourced the production of paper icons, woodcuts and synchōrochartia to other places including L'vov (L'viv, Lemberg), Wallachia, Chios (in the $17^{\text {th }}$ ce.) and Venice, Vienna, Petersburg, Constantinople (in the $18^{\text {th }}$ and $\left.19^{\text {th }}\right)$. See Papastratou (1981), p. 19.

${ }^{24}$ The decision issued by the synod of Constantinople dealt primarily with the commemoration of the name of the Patriarch of Jerusalem in churches dedicated to the Holy Sepulcher in the Danubian principalities. The synodal letter assured readers that the Church keeps the order (taxis) of its institutions. Still, certain customs of unclear origin but of beneficial aims and certainly not against the holy rules are to be continued as well. Examples of such customs are the distribution of synchōrochartia "everywhere" (pantachou) by the Patriarch of Jerusalem and his peregrinations everywhere without any obstacle in search of alms and help for the Holy Land. The former custom is practiced "because of divine and fire-like zeal, love and piety that all those who preceded us exhibited in an obligatory manner to the reverent and god-accepting
} 
the game" were commonly agreed and well spelled out. At the same time, the case of Ananias illustrates the fact that the patriarchates through a synod, had developed a mechanism of close communication among them, and a robust enforcement mechanism to effectively implement the commonly agreed rules in distributing indulgencies.

\subsection{Market Segmentation Monitoring and Enforcement Mechanism}

The case of Ananias illustrates the reaction of patriarchates to anybody that would like to violate the joint agreement among them on how to issue and distribute indulgences. Moreover, the case of Gerasimos II Paladas presents quite interesting caveats on the joint position that the patriarchates had developed on issuing and distributing indulgences.

Gerasimos Palladas served as patriarch of Alexandria in the period 1688-1710. ${ }^{25}$ Having resigned his throne, he apparently printed and distributed indulgences outside his diocese causing the consternation of both his successor and of the Patriarch of Jerusalem who claimed the synodal letter of the 1709 synod to their support. Based on their reference to the synodal letter, it seems that during the 1709 synod, it was generally agreed that only the Patriarch of Jerusalem could distribute indulgences everywhere, while all others were allowed to distribute indulgences only in their jurisdiction.

Sepulcher, which is above all the most worthy of reverence, supreme and most excellent location," the place where the drama of salvation was played out. See Papadopoulos-Kerameus (1891-1898), vol. 2, p. 381-84, quote 382. On the issue of commemoration, see also Chrysanthos' letter to the pacharnikos of Wallachia, dated December 1709, in Stathē (1999), p. 122-123, and appendix, 297-305.

${ }^{25}$ See Chatzoglou-Mpalta (2006). 
Given that in the 1690s, the patriarchs appear to have solidified their monopoly on distribution of indulgences using the Ananias case, in the 1709 synod they finally made the above mentioned decision. Thus, Gerasimos Palladas was violating these rules by distributing indulgences outside his jurisdiction. For that, Gerasimos Palladas was criticized by his successor to the throne of Alexandria Samouel Kapasoulēs. ${ }^{26}$

All in all, the above mentioned synodal letter indicates the existence of at least a common understanding among the key patriarchates of a certain and commonly acceptable way to distribute indulgences in the Eastern Orthodox world. In economic terms, patriarchates explicitly had segmented the market and this was considered an effective mechanism to monitor among themselves those that were violating the commonly agreed rules. Since Gerasimos Palladas appeared to deviate with his actions from this common understanding, the synod was an effective communication and monitoring mechanism to identify possible "defectors" from the commonly agreed rules to distribute indulgencies and the synodal letter was embodying the joint decisions to effectively enforce the indulgencies' distribution agreement among the "official" issuers of indulgencies.

\subsection{Product Innovation}

Product innovation is a company tactic to break through in an industry (and overcome industry barriers to entry) by appealing to a group of customers that are the first ones who actually try the product (see Chandler 2004). Most frequently, the newcomer, in order to quickly attract customers and establish himself tends to aggressively lower the price of

${ }^{26}$ See Papadopoulos-Kerameus (1912) p. 67-68. 
his product. This particular tactic is matched by a price drop by the incumbents and a price war evolves that leads to fierce competition among competitors (Suslow 2005 for instance). Thus product innovation creates market demand uncertainty (Suslow 2005) and a decline in market shares for the incumbents that, destabilizes any possible collusive behavior in the industry (Porter, 1993).

In indulgencies, there is absolutely no innovation in product attributes. The salvation and sin redemption properties for indulgencies (key product attributes) remain intact through the centuries, as far as the indulgencies are issued by the "official" issuers. Moreover, even in their form and structure as written documents, they show little change through the centuries.

\section{Discussion and Conclusions}

In our paper we focus on the distribution of indulgencies in the Eastern Orthodox Church. Despite the unconventional product and the unusual status of the institutions that issue indulgencies, we find evidence of collusive behavior among the issuers of indulgencies. The structure and the rules that support the distribution of indulgencies remained intact for centuries indicating a cartel case that managed to last for centuries. ${ }^{27}$

The analysis shows that only the four patriarchates possessed solely the right to issue and distribute indulgences and that was the outcome of a jointly agreed position among them. Thus, the legitimacy for issuing indulgencies were kept among few institutions through the centuries and this presents a high barrier to entry in issuing and

\footnotetext{
${ }^{27}$ Notice here that, we neither claim nor have any evidence to indicate that faithful were abused by the oligopolistic power of the issuers of indulgencies. Actually, there is evidence that shows that revenue from indulgencies was not the main source of revenue-collection from Patriarchia. Perhaps, the collusive behavior we observe had more of a territorial importance for Patriarchia. Of course, more on this issue might be the focus of another study.
} 
distributing indulgencies. Furthermore, patriarchates appeared to be quick in protecting their right by prohibiting others from issuing and distributing indulgences. Those who were not entitled to issue and distribute indulgencies, were condemned and excommunicated and thus were entirely discredited as legitimate distributors of indulgencies.

At the same time Patriarchia appear to have developed a set of rules in segmenting the territories for distributing indulgencies and also a mechanism to monitor the distribution of indulgences by preventing themselves from distributing indulgences outside of their jurisdiction. Moreover, through synods and synodal letters, they developed an enforcement mechanism to quickly "punish" anybody who was deviating from the commonly agreed rules. Finally, indulgencies never evolve, in terms of product attributes, through centuries, and this luck of innovativeness decisively contributed in stabilizing the structure that supports the distribution of indulgencies.

These findings are consistent with the relevant literature on cartel duration and collusive behavior (see for instance Dick (1996), Gensesove and Mullin (2001), Greeif (1993), Humphreys and Ruseski (2009), Levenstein and Suslow (2006), Suslow (2005) and Symeonidis (2003). The long duration of the collusive structure to distribute indulgencies boil down to strong barriers to entry, effective monitoring and an efficient enforcement mechanism and a lack of any serious product innovation through the centuries. Of course, in our analysis is not clear what are the intentions for this collusive behavior. This is actually part of a future research. However, it is remarkable to see how a collusive behavior on a non-conventional product by non-for-profit institutions can last for centuries. 
Finally, our research reveals significant evidence of other types of oligopolistic behavior in issuing and distributing indulgencies, such as price discrimination, price wars, and bundling. However, it is within our future research plans to explore these issues more thoroughly. 


\section{References}

Amantos, K., 1953, Syntomos Istoria tēs Hieras Monēs tou Sina, Thessaloniki

Andreadēs, Ioannēs, 1940, Historia tes en Chiō Orthodoxou Ekklēsias part 1, Athens

Argentē and Kyriakidēs, eds., 1946, Hē Chios para tois geografois kai periegetais apo tou ogdoou mechri tou eikostou aionos 3 vols. Athens

Asdrachas, Spiros, 1979, Agores kai time tou sitariou sten Hellada to IH' aiona, in: idem ed., He oikonomike dome ton Valkanikon choron (15os-19os aionas), Athens: Melissa

Chandler, Alfred D., 2004, Scale and Scope: The Dynamics of Industrial Capitalism, Belknap Press

Chasiotēs, I.K., 1969, To Oikoumeniko patriarcheio kai hē Krētē meta to thanato tou Kyrillou A' tou Loukareōs. Anekdota grammata tou patriarchē Partheniou A'(1639), Thēsaurismata vol. 6, 201-236

Chatzoglou-Mpalta, Elenē, 2006, Gerasimos B' Palladas. Patriarchēs Alexandreias (+1625/30-1714): Ho vios kai to syngrafikon tou ergon, Athens

Chrysochoidēs, Kriton, 2003, Hiera apodēmia. To proskynēmatiko taxidi stous Hagious Topous sta metavyzantina chronia, in Iolē Viggopoulou, ed. To Taxidi apo tous archaious ēos tous neōterous chronous, Athens

Crusius, Martinus, 1584, Turcograeciae libri octo, Basel

Dositheos, Patriarch of Jerusalem, 1908, "Historia tēs episkopēs tou Orous Sina," in Papadopoulos-Kerameus, ed., Symvolai eis tēn historian tēs archiepiskopēs tou Orous Sina, Pravoslavnyi Palestinskii Sbornik, v. 58, St. Petersburg

Fomenko, K1., 1900, Zametka o 'razreshitel'noi liturgii,' sovershaemoi na Golgofe. (Iz zapisok puteshestvenika v Sviatuiu Zemliu), Tserkovnye vedomosti no. 25

Gregoriadēs, Periklēs, 1875, Hē hiera mone tou Sina kata tēn topografikēn, istorikēn kai dioikētikēn autēs epopsin, Jerusalem

Iliou, Filippos, 1983, Synchōrochartia, Ta Historika, 1-1, 35-84

Iliou, Filippos., 1985, Synchōrochartia, Ta Historika, 2-3, 3-44

Konortas, Paraskeuas, 1986, Les contributions ecclésiastiques 'patriarchikè zèteia' et 'basilikon charatzion.' Contribution à l' histoire économique du patriarcat oecuménique aux XVe et XVIe siècles, in Economies mediterraneennes, equilibres et 
intercommunications 13 - 19e siecles : actes du Colloque International d'Histoire (2e : 1983 : 12-25 Sept. Athens, vol. 3: 217-255.

Konstantinos iereas Filippoupolitēs, 1819, Encheiridion peri tēs eparchias Filippoupolēōs, $\overline{\mathrm{e}}$, perigrafē autēs, Vienna

Kremmydas, V., 1972, To emporio tes Peloponnesou sto 18o aiona (1715-1792), Athens

Levenstein, Margaret and Valerie Suslow, 2006, What Determines Carter Success?

Journal of Economic Literature, vol. XLIV, 43-95

Liata, Eytychia D., 1999, Flōria dekatessera stenoun grosia saranta: Hē kykloforia tōn nomismatōn ston helleniko chōro, 15os-19os ai., Athens

Likhachev, N.P., 1894, “O razreshitel'nykh gramotakh vostochnykh patriarkhov," Drevnosti: Trudy Imperatorskogo Moskovskogo Arkheologicheskogo Obshchestva, 15 2: 77-99

Myrtilos Apostolidēs, Kosmas, 1959, He tēs Filippoupoleōs historia apo tōn archaiotatōn mechri tōn kath’ hēmas chronōn, Athens

Nikas, Constantino, 1998, I primi tentativi di latinizzazione dei Greci di Napoli e le prime "carte assolutorie" orientali in occidente, Napoli

Pallas, Dēmētrios I., 1955, Katalogos cheirografōn tou Vyzantinou Mouseiou Athenon, Athens

Papadopoulos, Chr., 1912, Samouēl Kapasoulēs, Papas kai Patriarchēs Alexandreias,(1661-1723), Alexandreia

Papadopoulos-Kerameus, A., 1884, Maurogordateios vivliothēkē, ètoi genikos perigrafikos katalogos tōn en tais ana tēn Anatolēn vivliothēkais, Istanbul

Papadopoulos-Kerameus, A., 1891-1898, Analekta Hierosolymitikēs Stachyologias, 5 volumes, St. Petersburg

Papastratou, Ntore, 1981, Ho Sinaitēs Chatzekyriakēs ek Chōras Vourla. Grammata, xylographies 1688-1709, Athens

Patriarchate of Constantinople, Archives, Kōdix Kypriou, Ad/1 (1720)

Patriarchate of Constantinople, Archives, Kōdix Kritiou, Ad/2 (1731-1737)

Patriarchate of Jerusalem, Archives, codex VI.D, no. 2 (Covering the years 1731-1755) 
Patriarchate of Jerusalem, VI.6 (Codices of the Head Secretariat), no. 12 (epistles of Dositheos)

Russian State Archive of Ancient Documents (RGADA), fond 1182, Moskovskii Pechatnyi Dvor (Muscovite Printing Office)

Roussos-Melidonēs, Markos N., n.d., Fragkiskanoi kai Kapoukinoi: 400 Chronia prosfora stous Hellenes 1585-1995, Athens

Roussos-Melidonēs, Markos N., 1991, Iesouites ston helleniko choro (1560-1915), Athens

Stathē, Penelope, 1984, To anekdoto odoiporiko tou Chrysanthou Notara, Mesaiōnika kai Nea Hellenika 1, 127-280

Stathē, Penelope, 1999, Chrysanthos Notaras, Patriarchēs Hierosolymōn: Prodromos tou Neohellenikou Diafōtismou, Athens

Stigler, George, 1964, The Theory of Oligopoly, Journal of Political Economy, 72-1, 4461

Svoronos, N., 1956, Le commerce de Salonique au XVIIIe siècle, Paris

Ta peri tēs eklogēs kai cheirotonias Archiepiskopou Sina episēma engrafa, 1860, Jerusalem

To kanonikon dikaion tou Patriarchikou Thronou tōn Ierosolymōn epi tēs archiepiskopēs Sina, epimartyroumenon hypo Episēmōn Ekklēsiastikōn Engrafōn, 1868, Constantinople

Zolōtas, Georgios I., 1928, Historia tes Chiou, 3 vols. in 5 parts, Athens 
Table 1: Number of indulgences issued in the $17^{\text {th }}$ Century

\begin{tabular}{|cllcl|}
\hline DATE & PATRIARCH & \multicolumn{1}{c}{ CLERIC } & NUMBER & $\begin{array}{c}\text { ADDITIONAL } \\
\text { INFORMATION }\end{array}$ \\
\hline 1653 & Constantinople & $\begin{array}{l}\text { Patriarch } \\
\text { Athanasios III } \\
\text { Patellaros }\end{array}$ & 500 & in Slavic \\
1655 & Serbian & "Patriarch" Gavriel & 1000 & \\
1668 & Antioch & Patriarch Makarios & 2000 & \\
1669 & Alexandria & Patriarch Pasios & 1500 & $\begin{array}{l}1000 \text { for men } \\
\text { and } 500 \text { for } \\
\text { women }\end{array}$ \\
\hline
\end{tabular}

Source: See detailed account in Appendix-A1 
Table 2: Number of indulgences and corresponding prices issued by Patriarch Chrysanthos of Jerusalem, in the $18^{\text {th }}$ Century

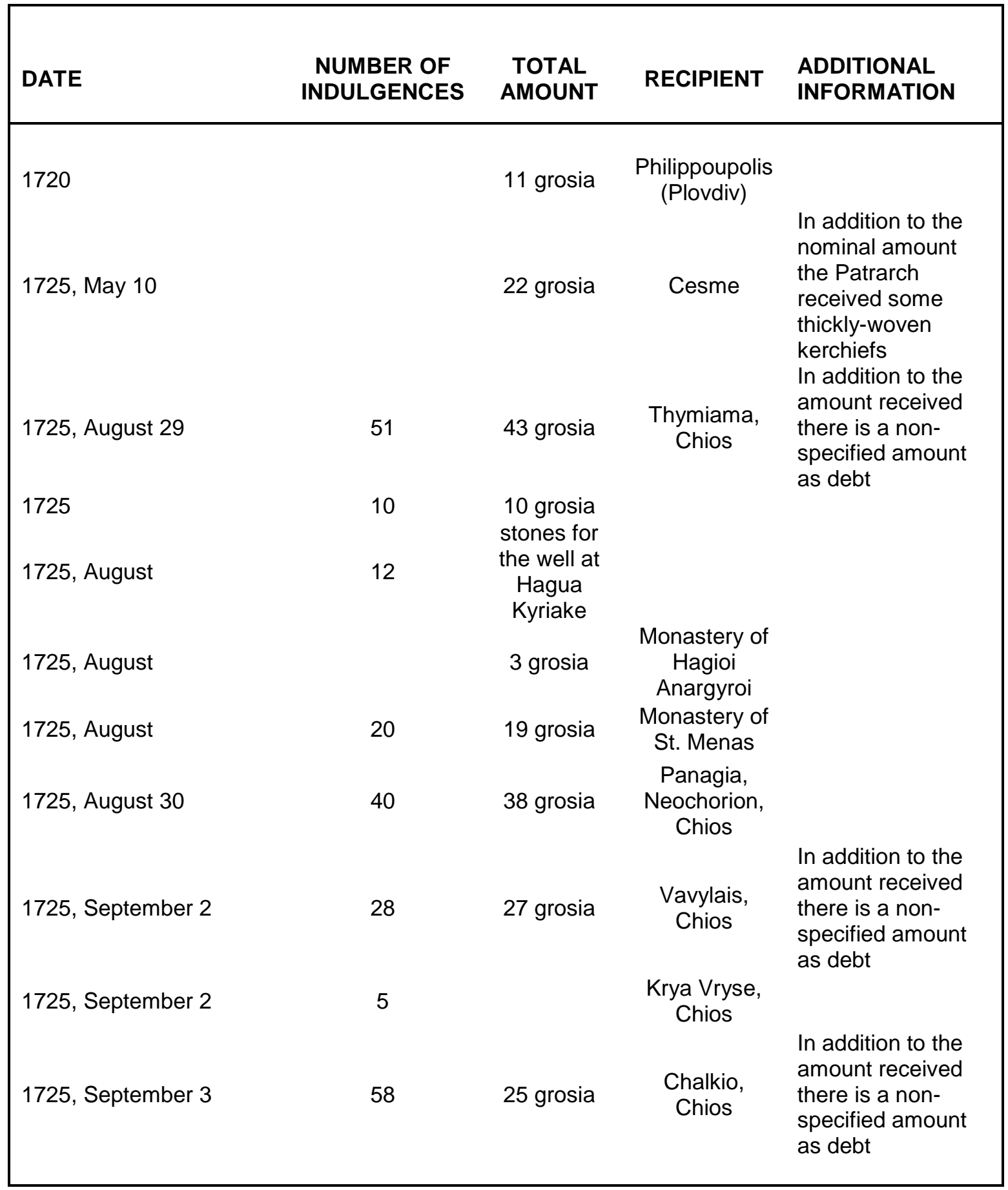

Source: See detailed account in Appendix-A2 


\section{Appendix}

\section{A1. Indulgences in the 17th century}

Table 1 was constructed by using the following primary and secondary information:

1) In 1653, the former Patriarch of Constantinople, Athanasios III Patellaros (on the patriarchal throne twice, in 1634 and in 1652) petitioned Tsar Aleksei Mikhailovich (1645-1676) to allow the printing of 500 such letters in Slavic (meant for use in Ukraine among Cossacks, as the patriarch specified). ${ }^{28}$

2) In 1655, the Serbian "Patriarch" Gavriel succeeded in having 1000 of them printed with the consent of Patriarch Nikon.

3) In 1668, Patriarch Makarios of Antioch (1647-1685) printed 2000.

4) In 1669, Patriarch Paisios of Alexandria (1657-1678) printed 1,000 for men and 500 for women. ${ }^{29}$

\footnotetext{
${ }^{28}$ See Likhachev (1894), p.78-80.

${ }^{29}$ See $R G A D A$, fond 1182, op. 1: d. 57, 11. 38-39v (Gavriel); d. 58, 1.177 (Makarios); d. 66, 1. 24 (Paisios). See also Likhachev (1894), pp. 78-81. It should be noted that Likhachev also refers to a printed indulgence issued in the name of Paisios Ligarides, one of the well-known protagonists in the deposition of Patriarch Nikon. He does not specify to whom it was offered: ibid., 83. For a first attempt at compiling lists of print runs since the seventeenth century, see Iliou (1983) and (1985).
} 


\section{A2. Number of indulgences and corresponding prices issued in the 18th Century}

A noticeable amount of information for the trade of indulgences is given by Patriarch

Chrysanthos. More specifically, in the account of his itinerary, visiting Orthodox

communities in Asia Minor and the Balkans, Chrysanthos noted in detail all the monetary

contributions of the believers to him for various aims: for help to the Holy Sepulcher,

memorial services, blessings, charity, and, what is the interest of this study,

indulgences. ${ }^{30}$ The cases where such a reference to indulgences exists are listed figured

occasionally in his notes. The following are these cases:

a) Not dated but must be 1720, near Philippoupolis (Plovdiv): "The priests from

Nterentzikioi and collectively from the same village [gave] us 11 grosia and asked for synchōrochartia and we gave them."31

b) May 10, 1725 in Cesme: "we also gave some synchōrochartia, from which

[transactions] we got 22 grosia and some thickly-woven kerchiefs

(chondromandēla).,32

c) August 29, 1725 in the village of Thymiana, Chios:

\footnotetext{
${ }^{30}$ See Stathe (1984), p. 127-280 (the text is on pp. 157-280), and an insert map between pp. 272-273. See also http://www.fhw.gr/projects/notaras/index.php?view=d4d

${ }^{31}$ See Stathe (1984), p. 185. On the village of Nteretzikioi (Deretsikiogi, or Pristitsa or Prastovitsa, modern Brestovica in Plovdiv district), see Konstantinos iereas Filippoupolitēs (1819), 47, (the inhabitants are all involved in viticulture). Aparently, a number of villages in the area had converted to Catholicism: on seventeenth-century efforts at proselytism by Catholic missionaries in the area of Philippoupolis, see Myrtilos Apostolidēs (1959), 240-243. There was also a metochi of the Holy Sepulcher in the city: ibid, 255 , fn. 11.

${ }^{32}$ See Stathe (1984), p. 259-260. Stathē notes that no other mention of synchōrochartia is made during Chrysanthos' sojourn in other areas of Asia Minor, and wonders whether the reasons were economic (absence of disposable income) or cultural (society was more conservative, therefore the distribution might actually not be welcomed). Stathē leans more towards the latter explanation.
} 
- "we distributed to the Christians 51 synchōrochartia, from which we received 43 grosia, and they will give us the remaining amount."

- "afterwards, we sent father Paisios and he gave 10 synchōrochartia and he brought us 10 grosia."

- "separately, we gave to the stenakousous, that is, the stone cutters 12 synchōrochartia so that they would bring stones for the well at Hagia Kyriakē. ${ }^{33}$ We left for the Monastery of Hagioi Anargyroi. The abbot [gave us] 2 touralia, ${ }^{34}$ and from the synchōrochartia of the [monastic] fathers 3 [grosia]. Then we climbed up to St. Mēnas [monastery], ${ }^{35}$ and we again listened to the holy liturgy. We gave 20 synchōrochartia and we received 19 [grosia]. ${ }^{, 36}$

\footnotetext{
${ }^{33}$ The Church of Hagia Kyriakē had been dedicated to the Holy Sepulcher by a chrysovoullon of Ioannēs Nikolaos Alexandrou Mavrokordatos, the voevoda of Moldavia and Wallachia in 1714: see Andreadēs (1940), appendix, pp. XXXIX-XLII.

${ }^{34}$ The tourali (Turkish tugrali) was a Turkish coin whose equivalence was: 1 golden Egyptian tougrali=315 aspra; 1 new grosion tugrali=120 aspra. See Stathē (1984), pp. 188, fn. 27. Also, Liata (1999)

${ }^{35}$ On the monasteries of Hagioi Anargyroi and of Hagios Mēnas, see Zolōtas (1928), v. 3, pt. 2: 323 and 323-330 respectively; also, Andreadēs (1940), pp. 308-13 and 297-302 respectively (and appendix, pp. CCLI-CCLIV and pp. CCXXXVI-CCXLIII for documents concerning them. Both monasteries were stauropégia of the Patriarchate of Constantinople, which obviously explains Chrysanthos' visit. Patriarchal stauropégia were under the control of commissioners elected from among the rich Greek community of Chios: ibid., appendix, p. CCLIV, fn. 1.

${ }^{36}$ Just for comparison's sake, in 1720 Chrysanthos sold a house that was left by a chatzēs to the Holy Sepulcher for 100 grosia: Stathē (1984), pp. 188. And when Chrysanthos sent from Kadikoy near Istanbul a monastic elder to Adrianople, he provided him 41 and a half grosia for transportation, tariffs, and other expenses: ibid, 188. When he sent the monastic elder Meletios to Thessaloniki, he gave him 15 grosia for his expenses: ibid., 189. A workshop (ergastēri) in the covered market (bezesten) of Giampolē, dedicated to the Holy Sepulcher, was sold for 30 grosia: ibid, 194. A house in the same location was sold for 20 grosia: ibid, 194. But in the latter two cases, it is also possible that the owners were already in debt and they simply dedicated the property to the Holy Sepulcher in order to get out of debt: see for a case of debt that led to a similar situation in Papastratou (1981), 33 (this is called prosēlosé, meaning that the indebted owner gives up ownership of property to an ecclesiastical organization, in this case the Sinai monks, gets the amount he owes and the monastery gets the property; also, ibid, 77-78, the price of a chandelier for a church, specially ordered by Chatzekyriakēs in Danzig is 350 grosia). For amounts of bribes given to various officials, see Stathe (1984), 208: the amounts range from 20 to 1,000 grosia. The leasing of a boat for a sea travel to Jaffa was 180 grosia (not including the cabin where he sat, Chrysanthos specifies). For skaliatika (tax for using the skala of the port to board a boat), for mainiatika (transportation fees) and for bribes Ananias, a monastic elder in Chrysanthos' entourage, paid 12 grosia: ibid. 213. In addition,
} 
- August 30 [in the original 20, but must be typo], Chios: "we left for

Neochorion. On the morrow we listened to the holy liturgy at the Panagia, performed an agiasmos and a sermon, set up a collection box (kouti) and we appointed commissioners (epitropous) [for the collection box][names of the commissioners follow]. We gave 40 synchōrochartia, from which we received 21 grosia and there remained 17. Later the village collectively gave to father Paisios 15 grosia". Most likely, the villagers collected money in order to pay the remaining amount owed.

- September 2, Chios: "We left for the Vavylais village. On the morrow we listened to the holy liturgy....performed an agiasmos and a sermon, set up a collection box... we gave 28 synchōrochartia, we received 27 grosia and there remained a debt left. We gave to the parish priest of Krya Vryse 5 synchōrochartia."

- September 3, in the village of Chalkio, Chios: "We performed an agiasmos... and a sermon, set up a collection box, appointed commissioners [names follow]. We gave 58 synchōrochartia and received 25 grosia and there remained a debt left." ${ }^{, 37}$

according to a sultanic firman, the newly appointed Metropolitan Daniel of Chios (1714-1741) was supposed to receive 12 aspra from each family and one florion from each priest per year: see Zolōtas (1928), vol. 3, pt. 2: 38. Finally, when the Abbot Michele Fourmont came to Chios in 1729, he visited the libraries of the Nea Monē and of Hagios Mēnas. In both locations, he managed to compile catalogs of the library holdings by slipping one grosi into the hands of the librarian monk for every visit: see Argente and Kyriakides, eds. (1946), vol. 2: 657. As another indication: the cost of transfer for the voyage from Jaffa to Chios in 1740 (while on return from pilgrimage to the Holy Land) was 22 grosia: see Chrysochoidēs (2003), p. 107.

${ }^{37}$ Stathē (1984), pp. 268-269. 